\title{
A Study on Changes in Antimicrobial Resistant Staphylococcus aureus from Wound Isolates in a South Korean University Hospital for the Past 10 Years (2006, 2016)
}

\author{
Seong-No Hong ${ }^{1}$, Joon $\mathrm{Kim}^{2}$, Hyun-Ho Sung ${ }^{1}$ \\ Department of Clinical Laboratory Science, Dongnam Health University, Suwon 16328, Korea \\ ${ }^{2}$ Department of Laboratory Medicine, Ajou University Hospital, Suwon 16499, Korea
}

\section{최근 10 년 동안 일개 대학병원 상처 배양에서 분리된 포도알균의 항생제 내성 변화 연구}

\author{
홍성노 ${ }^{1}$ 김 준 $^{2}$, 성현호 $^{1}$ \\ ${ }^{1}$ 동남보건대학교 임상병리과, ${ }^{2}$ 아주대학교병원 진단검사의학과
}

\begin{abstract}
Staphylococcus aureus, which is generally susceptible to the involvement route in community, is mostly MSSA. However, CA-MRSA is recently increased. Abuse of antibiotics and glycopeptides may increase VISA and VRSA. This study was conducted to investigate the changes on the antibiotic resistance prevalence and antibiotic susceptibility patterns of Staphylococcus aureus isolated from the wound of patients in a university hospital for the past 10 years. This study showed that antibiotic resistance was higher in males than in females; moreover, the antibiotic resistance rates increased with age. The resistance rate for penicillin, oxacillin, erythromycin, gentamicin, clindamycin, tetracycline, ciprofloxacin, fusidic acid, trimethoprim/sulfamethoxazole, clindamycin, and rifampicin was, respectively, $97.7 \%, 60.5 \%, 57.4 \%, 48.8 \%, 41.1 \%, 44.2 \%, 44.2 \%, 14.7 \%, 13.2 \%$ and $3.9 \%$ in 2006 . The resistance rate for penicillin, oxacillin, erythromycin, gentamicin, clindamycin, tetracycline, ciprofloxacin, fusidic acid, trimethoprim/sulfamethoxazole, fusidic acid, clindamycin, and rifampicin was, respectively 95.9\%, 62.6\%, 55.7\%, 28.6\%, 50.3\%, 34.7\%, 38.8\%, 34.0\%, $2.7 \%$ and $8.2 \%$ in 2016. Vancomycin, linezolid, quinupristin/dalfopristin, and teicoplanin exhibited $100 \%$ in antibiotic susceptibility. In particular, fusidic acid resistance was increased by $19.3 \%$ in 2016. Compared with 2006, the decreased point, $12.4 \%$ was susceptible and was statistically significant. Therefore, this study suggests that periodic review and understanding of microbial and antibiotic changes should continue to investigate appropriate antibiotic susceptibility.
\end{abstract}

Key words: Antibiotic resistance, Staphylococcus aureus, Wound infection

This is an Open Access article distributed under the terms of the Creative Commons Attribution Non-Commercial Licens (http://creativecommons.org/licenses/by-nc/4.0) which permits unrestricted non-commercial use, distribution, and reproduction in any medium, provided the original work is properly cited.

Copyright @ 2016 The Korean Society for Clinical Laboratory Science. All rights reserved.
Corresponding author: Hyun-Ho Sung Department of Clinical Laboratory Science, Dongnam Health University, 50 Cheoncheon-ro 74-gil, Jangan-gu, Suwon 16328, Korea

Tel: 82-31-249-6414

Fax: 82-31-249-6410

E-mail:wantyou7@dongnam.ac.kr

Received: August 16, 2016

Revised $1^{\text {st: }}$ September 9, 2016 Revised 2 ${ }^{\text {nd }}$ : September 28, 2016

Revised $3^{\text {rd }}$ : October 20, 2016

Accepted: October 24, 2016 


\section{서 론}

황색포도알균(Staphylococcus aureus, S. aureus)은 1880년 스코틀랜드의 외과의사 Alexander Ogston에 의해 무릎 관절 수술 중 농양에서 최초로 발견되었으며, 그리스어로 포도송이라는 의미 로 Staphylococcus라는 이름으로 명명하였으며, Staphylococcus aureus는 건강한 기니피그에 포도알균을 주입해서 얻어낸 농양에 서 황금색 균주를 분리하여 발견하여 라틴어로 황금색이라는 의미 로 명명되었다[1]. S. aureus는 페놀을 사용하여 국소 살균 치료에 한정되다가 1940년대에 페니실린(penicillin, PEN)이 약물로 사 용되었고 2년 후 페니실린 내성이 처음 발견된 후 1950년에는 그 내성의 빈도가 매우 증가되어 대체 약품이 연구되었다[2]. 1959년 beta-lactam계열의 메티실린(methicillin, MET)이 대체약품으로 개발되어 페니실린 분해효소를 생산하는 S. aureus를 치료하였으 나 1961년 메티실린 내성 황색포도알균(methicillin-resistant Staphylococcus aureus, MRSA)이 나타났다[3]. 이 후 메티실린 보다 안정적인 beta-lactam계열의 옥사실린(oxacillin, OXA), 플 루클록사신(flucloxacillin, FLX), 디클로사신(dicloxacillin, DCX) 등이 사용되었기 때문에 메티실린은 더 이상 상업적으로 생산되지 않고 있다[4]. 항생제는 항균제와 같은 의미로 세균 감염 치료 및 예 방에 사용하는 약물이다. 항생제는 종류별로 독특한 작용 방식을 가지고 있다. 항생제의 작용 원리는 세균의 세포벽과 같은 구조적 특징의 이해가 필수적이며, 항생제가 세균에 작용하는 기전은 세균 세포벽 합성 억제, 단백질 합성 억제, 핵산합성 및 활성억제, 엽산 등 세균 대사의 방해, 세포막 기능과 구조의 변형 등으로 분류할 수 있다[5]. 반코마이신(vancomycin, VAN)은 그람 양성균의 세포벽 합성과정에서 peptidoglycan 전구체인 D-alanyl-D-alanine과 결합하여 peptidoglycan 다중화에 필요한 transglycosylation, transpeptidation 과정을 차단함으로써 살균효과를 나타낸다. 클 린다마이신(clindamycin, CLI)은 대부분의 CA (Community-associated) MRSA (CA-MRSA)에 감수성이 있을 뿐 아니라 독소를 억 제하는 능력이 있어 관심이 증가하고 있지만, CA-MRSA가 생성하 는 PVL (panton-valentine leucocidin)을 효과적으로 억제하는 지에 PVL에 대해서는 아직 알려져 있지 않다. 후시딘산(fusidic acid, FUS)은 세균의 elongation factor G와 리보솜에 결합하여 세 균의 단백질 합성을 억제한다. 에리트로마이신(erythromycin, ERY) 과 겐타마이신(gentamicin, $\mathrm{GEN}$ )은 세균의 리보솜 $30 \mathrm{~S}$ 작용을 저 해하여 단백질 합성을 억제한다. 리네졸리드(linezolid, LNZ)는 최 초의 옥사졸리디온(oxazolidinone)계 정균 항생제로 리보솜 50S 와결합하여 단백질 합성의 초기단계를 방해한다. 옥사실린(oxacillin, OXA)과 페니실린은 세포벽에 작용하며, 리팜피신(rifampicin,
$\mathrm{RIF)}$ 은 세균의 RNA중합효소와 등몰비율로 결합하여 RNA합성 개 시를 저해하여 처음부터 합성되는 것을 방지한다. 트리메소프림 설 파메톡사졸(trimethoprim/sulfamethoxazole, SXT)은 hydrofolate 를 제거하여 tetrahydrofolate 생합성을 억제한다. 퀴누프리스틴 달포프리스틴(quinupristin/dalfopristin, SYN)는 cytochrome P450 효소의 활성을 억제하며, 테이코플라닌(teicoplanin, TEI)은 세균의 단백결합능력이 매우 우수하며, 테트라사이클린(tetracycline, TET)은 세균의 리보솜에 aminoacyl-tRNA 을 차단하여 단백질합성을 저해한다. 시프로플록사신(ciprofloxacin, CIP)은 DNA gyrase 와 a type II topoisomerase 그리고 topoisomerase $\mathrm{IV}$ 을 저해하여 세균의 세포분열을 억제한다[6-8]. 상처(wound) 는 피부가 빠르게 찢어져 절단되거나 천공되는 열린 상처 또는 외 상으로 인해 타박상이 발생하여 닫힌 상처로 구분하고, 병리학적으 로는 피부의 진피가 급격히 손상되는 것을 의미한다. 상처는 병원 성 미생물에 의해 통증, 발적, 고름이 나타나는 임상증상을 나타낸 다. S. aureus는 그람 양성세균으로 건강한 사람의 피부 및 점막에 약 $30 \%$ 서식하고 있으며, 피부 및 연조직 감염을 유발하는 강력한 병원균이다[9]. 또한, S. aureus 는 항생제 내성 균주의 광범위한 출 현으로 합병증의 발생률이 증가되어 미국에서는 감염 관련 사망의 주요 원인이 되고 있다[10]. 이러한 항생제의 살균효과로 인하여 $S$. aureus 감염을 치료를 목적으로 차단하기 위해 광범위한 사용과 항 생제의 낮은 농도 치료, 반코마이신 치료 실패, 당뇨병이나 면역저 하환자, 악성종양, 만성신부전, 잦은 수술환자 등의 기저질환을 가 지고 있는 환자로 인해 항생제 감수성이 저하되고, 내성이 증가하 고 있다. 현재 항생제 내성은 전 세계적인 문제로 확대되었으며, 아 시아권은 세계적으로 항생제 내성이 다른 지역에 비하여 월등히 높 은 지역에 속하며, 한국의 항생제 내성률은 세계적으로 손꼽을 수 있을 정도로 높은 실정이다[11]. MRSA는 면역력이 낮은 사람에게 상처가 있을 경우 병원이나 교도소, 양로원 등에서의 감염이 심각 한 문제가 될 수 있는데, 감염 경로에 따라 지역사회 관련 (community-associated, $\mathrm{CA}$ )의 개념과 병원과 연관된 경우를 의 료관련(healthcare-associated, $\mathrm{HA}$ )의 개념으로 분류하며, 가축 관련(livestock-associated)의 개념으로도 분류된다[12]. 일반적 으로 지역사회 관련 경로로 감염되기 쉬운 S. aureus는 대부분이 메 티실린 감수성 황색포도알균(methicillin-sensitive Staphylococcus aureus, MSSA)으로 알려져 있었으나, 최근 CA-MRSA가 증가하고 있으며, 원내 감염에 비해 지역사회감염 $\mathrm{MRSA}$ 의 발병 및 내성률이 증가하는 추세를 보이고 있다[13]. CA-MRSA 가 광범위하게 확산 되면서 1996년 일본에서는 vancomycin 중등도 내성 포도알균 (vancomycin-intermediate Staphylococcus aureus, VISA)이 처음 발견되었으며, 2002년 미국에서는 vancomycin 고도내성 포 
도알균(Vancomycin-resistant Staphylococcus aureus, VRSA) 이 최초로 보고되었다[14]. 이러한 배경으로 항생제와 glycopeptides 의 지속적인 남용이 우려되며, VISA, VRSA가 더욱 증가할 가능성 이 있다. 따라서 본 연구는 최근 10년간(2006년, 2016년) 일개 대 학병원의 wound에서 분리한 황색 포도상 구균의 항생제 감수성 패턴과 항생제 내성의 유병률의 변화를 조사하여 $\mathrm{MRSA}$ 의 전형적 인 원내감염의 위험이 높은 중환자나장기 입원 환자가 많은 3차 병 원에서 지역사회 감염 $\mathrm{MRSA}$ 의 증가를 확인하기 위한 기초자료로 사용하기 위하여 실시하였다.

\section{재료 및 방법}

\section{1. 연구 대상 및 균주}

2006년 1월부터 5월까지 그리고 2016년 1월부터 5월까지 수원 소재 일개 대학병원 환자의 wound에서 각각 분리한 $S$. aureus 대 상으로 하였다. 전체 276 균주 중 2006년은 129균주, 2016년은 147 균주를 비교하였다. 세균의 분리는 $6 \%$ 면양혈액이 함유된 배 지를 사용하여 $37^{\circ} \mathrm{C}$ 에서 18 시간 배양하였다. 분리된 세균은 coagulase 및 catalase시험을 실시하였으며, Vitek 32 GPI kit (BioMerieux, Craponne, France)를 이용하여 동정하였다. 총 622 균 주중 한 환자에서 2 회 이상 중복된 것은 1 회만 인정하여 총 276균주가 연구 대상이 되었다. Wound에서 S. aureus 균을 분리 한 환자 276 명의 연령에 따른 차이를 분석하기 위하여 헌법에서 구 분하는 법적 효력을 갖는 13 세 이전을 group 1,14 세부터 59세까 지 group 2, 노인복지주택을 입소할 수 있는 나이인 60세 이상을 group 3으로 조작적 정의를 하였다.

\section{2. 항생제 감수성 검사}

상처 배양검사에서 분리된 S. aureus의 항생제 감수성은 2011 년 Clinical and Laboratory Standards Institute (CLSI)에서 제시 한 기준에 따라 분석하였다[10]. 항생제는 세계보건기구의 표준품 으로 VAN, CLI, ERY, FUS, GEN, LNZ, OXA, PEN, RIF, SXT, SYN, $\mathrm{TEI}, \mathrm{TET}, \mathrm{CIP}$ 등 14종에 대한 감수성 검사를 실시하였다. 실시대
조 균주는 Staphylococcus aureus ATCC 29213을 사용하였다. 항생제 감수성의 판정은 디스크 확산법과 Vitek $2 \mathrm{kit}$ 를 이용한 최 소억제 농도(MIC) 판정을 이용하여 실시하였다. 디스크 확산법에 서의 판정 기준은 CLSI 가이드라인을 적용하였다[15].

\section{3. 통계 분석}

통계 분석은 SPSS 버전 21.0 프로그램(SPSS, Chicago, Illinois, USA)을 이용하였다. 모든 정성변수는 명목척도로 빈도분석을 실 시하였으며 백분율로 나타내었다. 연속변수는 평균과 표준편차로 표시했으며, 환자의 성별에 따른 연령의 차이는 independent t-test을 실시하였다. 성별과 연령대의 독립성과 2006년과 2016 년 항생제 감수성 결과차이를 분석하기 위하여 chi square test을 실시하였고 모든 통계적 유의수준은 $p<0.05$ 로 설정하였다.

\section{결 과}

\section{1. 대상자의 일반적 특성}

연구 대상자는 총 276 명이었으며, 남성 184 명(66.7\%), 여성은 92명(33.3\%)이었다. 전체평균연령은 $42.47 \pm 24.44$ 세였으며, 남 성은 $41.16 \pm 23.12$ 세, 여성은 $45.09 \pm 26.83$ 세였다. 성별에 따른 연령은 차이가 없는 동일한 집단으로 나타났다. 2006년 대상자는 총 129명이었고, 그 중 남성은 82명(29.7\%) 여성은 47명(17.0\%), 전체 연령은 $47.28 \pm 21.32$ 세, 남성은 $44.85 \pm 20.69$ 세, 여성은 $51.51 \pm 21.97$ 세였다. 2016년 대상자는 총 147 명이었고, 그 중남 성은 102 명(37.0\%), 여성은 45 명(16.3\%), 전체 연령은 $38.25 \pm 26.23$ 세, 남성은 $38.20 \pm 24.60$ 세, 여성은 $38.38 \pm 29.91$ 세였다. 2006 년도와 2016년의 연령별 분포의 차이는 통계적으로 유의하였다 $(p<0.01)$. 대상자의 일반적 특성은 Table 1에 제시하였다.

\section{2. 성별에 따른 항생제의 감수성 차이}

VAN, LNZ, SYN, TEI에서는 남성과 여성 모두에서 항생제 감수 성이 $100 \%$ 로 나타났다. ERY, FUS, OXA, PEN, RIF, SXT에서는 성 별에 따른 항생제 감수성의 유의한 차이가 없었으며, CLI은 항생제

Table 1. General characteristics of subjects

\begin{tabular}{|c|c|c|c|c|c|}
\hline \multicolumn{2}{|c|}{ Variable } & Total, n (\%) & Male, n (\%) & Female, n (\%) & $\mathrm{F} / \mathrm{t}$ \\
\hline \multirow[t]{3}{*}{ Age } & Total & $\begin{array}{c}277 \\
42.63 \pm 21.11\end{array}$ & $\begin{array}{c}186(67.1) \\
41.72 \pm 23.03\end{array}$ & $\begin{array}{c}91(32.9) \\
44.48 \pm 26.38\end{array}$ & $4.94^{\star} /-1.25$ \\
\hline & 2006 & $\begin{array}{c}131(47.3) \\
47.05 \pm 21.11\end{array}$ & $\begin{array}{c}85(30.6) \\
45.21 \pm 20.42\end{array}$ & $\begin{array}{c}46(16.6) \\
50.46 \pm 22.17\end{array}$ & $14.61 / 3.10^{\star \star}$ \\
\hline & 2016 & $\begin{array}{c}146(52.7) \\
38.66 \pm 26.33\end{array}$ & $\begin{array}{c}101(36.5) \\
38.78 \pm 24.73\end{array}$ & $\begin{array}{c}45(16.3) \\
38.38 \pm 29.9\end{array}$ & \\
\hline
\end{tabular}

Data were expressed as mean \pm SD.

${ }^{\star} p<0.05,{ }^{\star \star} p<0.01$. 
내성검사에서 남성이 98명(53.3\%), 여성이 29명(31.5\%)로 남성이 여성보다 내성에서 높은 비율을 나타내었으며, 감수성 검사에서는 남성이 85명(46.2\%), 여성이 62명(67.4\%)로 여성이 감수성에서 높은 빈도를 나타내었고 통계적으로 유의한 차이를 나타내었다 $(p$ $<0.01)$. GEN 내성검사에서는 남성이 $78(42.4 \%)$, 여성이 27명 (29.3\%)로 남성에게서 높은 비율을 나타내었으며, 감수성 검사에 서는 남성이 101명(54.9\%), 여성이 55명(59.8\%)로 여성에게서 높 은 비율을 나타내었고, 통계적으로 유의하였다 $(p<0.01)$. TET, $\mathrm{CIP}$ 의 내성 검사에서는 남성이 여성보다 높은 비율을 나타내었으 며, 감수성검사에서는 여성이 남성보다 높은 비율을 나타내었으 며, 통계적으로 유의하였다 $(p<0.05)$. Table 2에 제시하였다.

\section{3. 연령에 따른 항생제의 감수성 차이}

VAN, LNZ, SYN, TEI에서는 연령에 따른 항생제 감수성이 $100 \%$ 로 나타났다. FUS, OXA, PEN, RIF, SXT에서는 연령에 따른 항생제 감수성의 유의한 차이가 없었으며, CLI은 항생제 내성검사
에서 group 1에서 15명(26.3\%), group 2에서 75명(31.5\%), group 3 에서 37 명 $(50.0 \%)$ 의 비율로 나타나 연령이 증가함에 따라 내성의 비율이 높은 것으로 나타났으며, 통계적으로 유의하였다 $(p<0.05)$. ERY은 항생제 내성검사에서 group 1에서 22명(38.6\%), group 2 에서 90명(62.1\%), group 3에서 44명(59.5\%)의 비율로 나타났으 며, 통계적으로 유의한 차이를 나타내었다 $(p<0.01)$. GEN 내성 검 사에서는 group 1에서 6명(10.5\%), group 2에서 68명(46.9\%), group 3에서 31명(41.9\%)의 비율로 나타났으며, 통계적으로 유의 하였다 $(p<0.01)$. TET 내성 검사에서는 group 1에서 4 명 $(7.0 \%)$, group 2에서 64명(44.1\%), group 3에서 40명(54.1\%)의 비율로 나타나 연령이 증가함에 따라 내성의 비율이 높은 것으로 나타났으 며, 통계적으로 유의하였다 $(p<0.01) . \mathrm{CIP}$ 의 내성 검사에서는 group 1에서 1명(1.8\%), group 2에서 73명(50.3\%), group 3에서 40명(54.1\%)의 비율로 나타나 연령이 증가함에 따라 내성의 비율 이 높은 것으로 나타났으며, 통계적으로 유의하였다 $(p<0.01)$. Table 3에 제시하였다.

Table 2. Difference of antibiotic susceptibility by gender

\begin{tabular}{|c|c|c|c|c|c|c|}
\hline & Variable & & Resistance, n (\%) & Intermediate, $\mathrm{n}(\%)$ & Susceptibility, n (\%) & $x^{2}$ \\
\hline \multirow[t]{4}{*}{ Glycopetide } & VAN & Male & $0(0.0)$ & $0(0.0)$ & $184(100)$ & \\
\hline & & Female & $0(0.0)$ & $0(0.0)$ & $92(100)$ & \\
\hline & TEI & Male & $0(0.0)$ & $0(0.0)$ & $184(100)$ & \\
\hline & & Female & $0(0.0)$ & $0(0.0)$ & $92(100)$ & \\
\hline \multirow[t]{2}{*}{ Macrolide } & ERY & Male & $110(59.8)$ & $8(4.3)$ & $66(35.9)$ & 5.63 \\
\hline & & Female & $46(50.0)$ & $1(1.1)$ & $45(48.9)$ & \\
\hline \multirow[t]{2}{*}{ Licosamide } & CLI & Male & $98(53.3)$ & $1(0.5)$ & $85(46.2)$ & $11.72^{\star \star}$ \\
\hline & & Female & $29(31.5)$ & $1(1.1)$ & $62(67.4)$ & \\
\hline \multirow[t]{2}{*}{ Aminoglycoside } & GEN & Male & $78(42.4)$ & $5(2.7)$ & $101(54.9)$ & $10.50^{\star *}$ \\
\hline & & Female & $27(29.3)$ & $10(10.9)$ & $55(59.8)$ & \\
\hline \multirow[t]{2}{*}{ Oxazolidinone } & LNZ & Male & $0(0.0)$ & $0(0.0)$ & $184(100)$ & \\
\hline & & Female & $0(0.0)$ & $0(0.0)$ & $92(100)$ & \\
\hline \multirow[t]{4}{*}{ Penicillin } & OXA & Male & $119(64.7)$ & $0(0.0)$ & $65(35.3)$ & 2.21 \\
\hline & & Female & $51(55.4)$ & $0(0.0)$ & $41(44.6)$ & \\
\hline & PEN & Male & $177(96.2)$ & $0(0.0)$ & $7(3.8)$ & 0.51 \\
\hline & & Female & $90(97.8)$ & $0(0.0)$ & $2(2.2)$ & \\
\hline \multirow{2}{*}{ Sulfonamide } & SXT & Male & $17(9.2)$ & $0(0.0)$ & $167(90.8)$ & 2.08 \\
\hline & & Female & $4(4.3)$ & $0(0.0)$ & $88(95.7)$ & \\
\hline \multirow[t]{2}{*}{ Streptogramin } & SYN & Male & $0(0.0)$ & $0(0.0)$ & $184(100)$ & \\
\hline & & Female & $0(0.0)$ & $0(0.0)$ & $92(100)$ & \\
\hline \multirow[t]{2}{*}{ Tetracycline } & TET & Male & $83(45.1)$ & $3(1.6)$ & 98 (53.3) & $8.69^{\star}$ \\
\hline & & Female & $25(27.2)$ & $1(1.1)$ & $66(71.7)$ & \\
\hline \multirow[t]{2}{*}{ Quinolone } & CIP & Male & $86(46.7)$ & $2(1.1)$ & $96(52.2)$ & $7.70^{\star}$ \\
\hline & & Female & $28(30.4)$ & $3(3.3)$ & $61(66.3)$ & \\
\hline \multirow[t]{2}{*}{ Fusidic acid } & FUS & Male & $47(25.5)$ & $18(9.8)$ & $119(64.7)$ & 1.03 \\
\hline & & Female & $22(23.9)$ & $6(6.5)$ & $64(69.6)$ & \\
\hline \multirow[t]{2}{*}{ rifampicin } & RIF & Male & $11(6.0)$ & $1(0.5)$ & $172(93.5)$ & 0.28 \\
\hline & & Female & $6(6.5)$ & $1(1.1)$ & $85(92.4)$ & \\
\hline
\end{tabular}

${ }^{*} p<0.05,{ }^{* *} p<0.01$

Abbreviation: VAN, vancomycin; CLI, clindamycin; ERY, erythromycin; FUS, fusidic acid; GEN, gentamicin; LNZ, linezolid; OXA, oxacillin; PEN, penicillin; RIF, rifampicin; SXT, trimethoprim/sulfamethoxazole; SYN, quinupristin/dalfopristin; TEI, teicoplanin; TET, tetracycline; CIP, ciprofloxacin. 
Table 3. Difference of antibiotic resistance and susceptibility by age

\begin{tabular}{|c|c|c|c|c|c|}
\hline \multicolumn{2}{|c|}{ Variable } & \multirow{2}{*}{$\begin{array}{c}\text { Resistance, n (\%) } \\
0(0.0)\end{array}$} & \multirow{2}{*}{$\begin{array}{c}\text { Intermediate, } \mathrm{n}(\%) \\
0(0.0)\end{array}$} & \multirow{2}{*}{$\begin{array}{c}\text { Susceptibility, n (\%) } \\
57(100.0)\end{array}$} & \multirow[t]{2}{*}{$x^{2}$} \\
\hline VAN & Group 1 & & & & \\
\hline & Group 2 & $0(0.0)$ & $0(0.0)$ & $145(100.0)$ & \\
\hline & Group 3 & $0(0.0)$ & $0(0.0)$ & $74(100.0)$ & \\
\hline \multirow[t]{3}{*}{ CLI } & Group 1 & $15(26.3)$ & $0(0.0)$ & $42(73.7)$ & $12.54^{\star}$ \\
\hline & Group 2 & $75(51.7)$ & $1(0.7)$ & $69(47.6)$ & \\
\hline & Group 3 & $37(50.0)$ & $1(1.4)$ & $36(48.6)$ & \\
\hline \multirow[t]{3}{*}{ ERY } & Group 1 & $22(38.6)$ & $1(1.8)$ & $34(59.6)$ & $13.65^{\text {** }}$ \\
\hline & Group 2 & $90(62.1)$ & $7(4.8)$ & $48(33.1)$ & \\
\hline & Group 3 & $44(59.5)$ & $1(1.4)$ & $29(39.2)$ & \\
\hline \multirow[t]{3}{*}{ FUS } & Group 1 & $9(15.8)$ & $2(3.5)$ & $46(80.7)$ & 8.90 \\
\hline & Group 2 & $37(25.5)$ & $17(6.2)$ & $91(62.8)$ & \\
\hline & Group 3 & $23(31.1)$ & $5(6.8)$ & $46(62.2)$ & \\
\hline \multirow[t]{3}{*}{ GEN } & Group 1 & $6(10.5)$ & $8(14.0)$ & $43(75.4)$ & $29.28^{\star \star}$ \\
\hline & Group 2 & $68(46.9)$ & $5(3.4)$ & $72(49.7)$ & \\
\hline & Group 3 & 31 (41.9) & $2(2.7)$ & $41(55.4)$ & \\
\hline \multirow[t]{3}{*}{ LNZ } & Group 1 & $0(0.0)$ & $0(0.0)$ & $57(100.0)$ & \\
\hline & Group 2 & $0(0.0)$ & $0(0.0)$ & $145(100.0)$ & \\
\hline & Group 3 & $0(0.0)$ & $0(0.0)$ & $74(100.0)$ & \\
\hline \multirow[t]{3}{*}{ OXA } & Group 1 & $28(10.1)$ & $0(0.0)$ & $29(50.9)$ & 5.07 \\
\hline & Group 2 & $92(63.4)$ & $0(0.0)$ & $53(36.6)$ & \\
\hline & Group 3 & $50(67.6)$ & $0(0.0)$ & $24(32.4)$ & \\
\hline \multirow[t]{3}{*}{ PEN } & Group 1 & $54(94.7)$ & $0(0.0)$ & $3(5.3)$ & 3.57 \\
\hline & Group 2 & $139(95.9)$ & $0(0.0)$ & $6(4.1)$ & \\
\hline & Group 3 & $74(100.0)$ & $0(0.0)$ & $0(0.0)$ & \\
\hline \multirow[t]{3}{*}{ RIF } & Group 1 & $0(0.0)$ & $0(0.0)$ & $57(100.0)$ & 7.43 \\
\hline & Group 2 & $9(6.2)$ & $1(0.7)$ & 135 (93.1) & \\
\hline & Group 3 & $8(10.8)$ & $1(1.4)$ & $65(87.8)$ & \\
\hline \multirow[t]{3}{*}{ SXT } & Group 1 & $1(1.8)$ & $0(0.0)$ & $56(98.2)$ & 3.66 \\
\hline & Group 2 & $14(9.7)$ & $0(0.0)$ & $131(90.3)$ & \\
\hline & Group 3 & $6(8.1)$ & $0(0.0)$ & 68 (91.9) & \\
\hline \multirow[t]{3}{*}{ SYN } & Group 1 & $0(0.0)$ & $0(0.0)$ & $57(100.0)$ & \\
\hline & Group 2 & $0(0.0)$ & $0(0.0)$ & $145(100.0)$ & \\
\hline & Group 3 & $0(0.0)$ & $0(0.0)$ & $74(100.0)$ & \\
\hline \multirow[t]{3}{*}{ TEl } & Group 1 & $0(0.0)$ & $0(0.0)$ & $57(100.0)$ & \\
\hline & Group 2 & $0(0.0)$ & $0(0.0)$ & $145(100.0)$ & \\
\hline & Group 3 & $0(0.0)$ & $0(0.0)$ & $74(100.0)$ & \\
\hline \multirow[t]{3}{*}{ TET } & Group 1 & $4(7.0)$ & $0(0.0)$ & $53(93.0)$ & $35.69^{* *}$ \\
\hline & Group 2 & $64(44.1)$ & $3(2.1)$ & $78(53.8)$ & \\
\hline & Group 3 & $40(54.1)$ & $1(1.4)$ & $33(44.6)$ & \\
\hline \multirow[t]{3}{*}{ CIP } & Group 1 & $1(1.8)$ & $1(1.8)$ & $55(96.5)$ & $50.67^{\star \star}$ \\
\hline & Group 2 & $73(50.3)$ & $1(0.7)$ & $71(49.0)$ & \\
\hline & Group 3 & $40(54.1)$ & $3(4.1)$ & $40(54.1)$ & \\
\hline
\end{tabular}

${ }^{*} p<0.05,{ }^{* *} p<0.01$.

Abbreviation: See Table 2.

\section{10 년 동안의 항생제 감수성 변화}

VAN, LNZ, SYN, TEI에서는 2006년 그리고 2016년 모두 항생 제 감수성이 100\%로 나타났다. CLI, OXA, PEN, RIF 등은 2006년 과 2016년 동안 통계적으로 유의한 차이가 없었다. ERY은 항생제 내성검사에서 2006년 74균주(57.4\%), 2016년에서 82균주(55.7\%), 항생제 감수성 검사에서 2006년에서 46균주(35.7\%)의 2016년에 는 65 균주(44.2\%) 비율로 나타났으며, 통계적으로 유의한 차이를
나타내었다 $(p<0.01)$. FUS 항생제 내성검사에서 2006년에서 19 균주(14.7\%)의 2016년에는 50균주(34.0\%) 비율로 나타났으며, 통계적으로 유의한 차이를 나타내었다 $(p<0.01)$. GEN 내성 검사 에서는 2006년에서 63균주(48.8\%)의 2016년에는 42균주 (28.6\%) 비율로 나타났으며, 통계적으로 유의한 차이를 나타내었 다 $(p<0.01)$. SXT 내성 검사에서는 2006년에서 17균주(13.2\%)의 2016년에는 4균주 $(2.7 \%)$ 비율로 나타났으며, 통계적으로 유의한 차이를 나타내었다 $(p<0.01)$. TET 내성 검사에서는 2006년에서 
340 Seong-No Hong, et al. Changes in Antimicrobial Resistant Staphylococcus aureus from the Wound Isolates

Table 4. Change of antibiotic resistance and susceptibility in 10 years

\begin{tabular}{|c|c|c|c|c|c|}
\hline \multicolumn{2}{|c|}{ Variable } & \multirow{2}{*}{$\frac{\text { Resistance, } \mathrm{n}(\%)}{0(0.0)}$} & \multirow{2}{*}{$\frac{\text { Intermediate, } \mathrm{n}(\%)}{0(0.0)}$} & \multirow{2}{*}{$\begin{array}{c}\text { Susceptibility, n (\%) } \\
129(47.3)\end{array}$} & \multirow[t]{2}{*}{$x^{2}$} \\
\hline VAN & 2006 & & & & \\
\hline & 2016 & $0(0.0)$ & $0(0.0)$ & $147(48.4)$ & \\
\hline \multirow[t]{2}{*}{$\mathrm{CLI}$} & 2006 & $53(41.1)$ & $0(0.0)$ & $76(59.9)$ & 4.48 \\
\hline & 2016 & $74(50.3)$ & $2(1.4)$ & $71(48.3)$ & \\
\hline \multirow[t]{2}{*}{ ERY } & 2006 & $74(57.4)$ & $9(7.0)$ & $46(35.7)$ & $11.53^{\text {** }}$ \\
\hline & 2016 & $82(55.7)$ & $0(0.0)$ & $65(44.2)$ & \\
\hline \multirow[t]{2}{*}{ FUS } & 2006 & $19(14.7)$ & $16(12.4)$ & $94(72.9)$ & $15.62^{* *}$ \\
\hline & 2016 & $50(34.0)$ & $8(5.4)$ & $89(60.5)$ & \\
\hline \multirow[t]{2}{*}{ GEN } & 2006 & $63(48.8)$ & $4(3.1)$ & $62(48.1)$ & $12.91^{\star \star}$ \\
\hline & 2016 & $42(28.6)$ & $11(7.5)$ & $94(63.9)$ & \\
\hline \multirow[t]{2}{*}{ LNZ } & 2006 & $0(0.0)$ & $0(0.0)$ & $129(47.3)$ & \\
\hline & 2016 & $0(0.0)$ & $0(0.0)$ & $147(48.4)$ & \\
\hline \multirow[t]{2}{*}{ OXA } & 2006 & $78(60.5)$ & $0(0.0)$ & $51(39.5)$ & 1.31 \\
\hline & 2016 & $92(62.6)$ & $0(0.0)$ & $55(37.4)$ & \\
\hline \multirow[t]{2}{*}{ PEN } & 2006 & $126(97.7)$ & $0(0.0)$ & $3(2.3)$ & 0.67 \\
\hline & 2016 & $141(95.9)$ & $0(0.0)$ & $6(2.2)$ & \\
\hline \multirow[t]{2}{*}{ RIF } & 2006 & $5(3.9)$ & $2(1.6)$ & $122(94.6)$ & 4.38 \\
\hline & 2016 & $12(8.2)$ & $0(0.0)$ & $135(91.8)$ & \\
\hline \multirow[t]{2}{*}{ SXT } & 2006 & $17(13.2)$ & $0(0.0)$ & $112(86.8)$ & $10.68^{\star *}$ \\
\hline & 2016 & $4(2.7)$ & $0(0.0)$ & $143(97.3)$ & \\
\hline \multirow[t]{2}{*}{ SYN } & 2006 & $0(0.0)$ & $0(0.0)$ & $129(47.3)$ & \\
\hline & 2016 & $0(0.0)$ & $0(0.0)$ & $147(48.4)$ & \\
\hline \multirow[t]{2}{*}{ TEI } & 2006 & $0(0.0)$ & $0(0.0)$ & $129(47.3)$ & \\
\hline & 2016 & $0(0.0)$ & $0(0.0)$ & $147(48.4)$ & \\
\hline \multirow[t]{2}{*}{ TET } & 2006 & $57(44.2)$ & $4(3.1)$ & $68(52.7)$ & $7.97^{\star}$ \\
\hline & 2016 & $51(34.7)$ & $0(0.0)$ & $96(65.3)$ & \\
\hline \multirow[t]{2}{*}{ CIP } & 2006 & $57(44.2)$ & $2(1.6)$ & $70(54.3)$ & 0.87 \\
\hline & 2016 & $57(38.8)$ & $3(2.0)$ & $87(59.2)$ & \\
\hline
\end{tabular}

${ }^{*} p<0.05,{ }^{* *} p<0.01$.

Abbreviation: See Table 2.

57균주(44.2\%)의 2016년에는 4명(34.7\%) 비율로 나타났으며, 통 계적으로 유의한 차이를 나타내었다 $(p<0.05)$. Table 4에 제시하 였다.

\section{고 찰}

수원 소재 1 개 대학병원 환자의 상처에서 각각 분리한 $S$. aureus 대상으로 빈도분석과 성별과 연령 그리고 2006년도와 2016년도 항생제 내성의 차이를 전체 276 균주 중 2006년은 129균주, 2016 년은 147 균주를 비교하였다. 본 연구에서 남녀의 비는 184 명:92명 으로 남성이 $66.7 \%$ 를 차지하였다. 남녀에 따른 연령별 분포의 차이 는 없는 것으로 나타나, 상처에서 분리한 $S$. aureus는 성별에 따른 동일한 집단으로 분석되었으나, 2006년과 2016년 연령의 분포의 차이는 통계적으로 유의한 차이를 보였다. 이는 S. aureus 가 성별 및 연령에 따라 다르게 존재하기 때문으로 생각된다[16]. 또한, 해 외선행논문에 따르면 $S$. aureus 유병률은 외래 환자에 비해 입원 환 자에서 높았으며, 여성에 비해 남성들 사이에서 높은 유병률을 보
였는데, 베타-락타마제 암피실린은 입원 환자의 $81.5 \%$ 와 외래 환 자에 대한 $60.7 \%$ 로 모든 항생제의 가장 높은 $60.7 \%$ 붙 내성을 나타 내었으며, GEN은 내성 균주가 거의 발견되지 않았다[17]. 이번 연 구에서도 남성이 여성보다 항생제 내성이 높게 나타났는데, 특히 CLI, ERY, GEN, TET, CIP에서 통계적으로 유의한 차이를 나타냈 다. 연령에 따른 차이는 CLI, GEN, TET, CIP등에서 통계적으로 유 의한 차이를 나타내었는데, 14 세 이전에서 분리한 균주보다 14 세 에서 59세, 60 세 이상에서 분리한 균주에서 더 높은 내성을 나타내 었다. PEN은 60세 이상에서 $100 \%$ 의 내성을 나타내었다. S. aureus 균주에 대한 항생제 감수성에 대한 선행논문에 따르면, 2005 2007년에 40여개의 병원에서 $S$. aureus의 항생제 내성은 PEN이 $93 \%$, 나타났고, OXA, ERY, GEN, CLI 등이 각각 $59.8 \%, 59.2 \%$, $51.75 \%, 50.7 \%$ 로 나타났다[18]. 또한, 일개 종합병원 입원환자를 대상으로 검사실에서 분리한 $S$. aureus의 항생제 내성률을 조사한 결과, PEN, CLI, TET, ERY에 대해 각각 $98 \%, 53 \%, 49 \%, 38 \%$ 의 내 성이 나타났으며[19], 2009년 1년간 9개의 종합병원에서 분리된 S. aureus 의 PEN, OXA, ERY에 대한 내성은 각각 $95 \%, 70 \%, 61 \%$, 
CLI와 TET에 대한 내성은 64\%와 56\%를 나타냈다[20]. 본 연구에 서는 2006년 PEN의 내성율은 97.7\%였으며, 2016년에는 95.9\% 로 나타내었다. OXA는 2006년 60.5\%, 2016년 62.6\%로 나타났고 ERY은 2006년 57.4\%, 2016년 55.7\%로 나타났다. GEN은 2006 년 48.8\%, ERY은 55.7\%로 나타났다. 2016년에 28.6\%였으며, CLI 은 2006년 41.1\%, 2016년 50.3\%로 유사한 결과로 분석되었다. 또 한, 2006년 S. aureus 80 균주에 대한 내성률은 FUS는 $17.5 \%$, TET 는 $13.8 \%$, GEN은 $7.5 \%$, SXT는 $6.3 \%$, ERY는 $3.8 \%$, CLI는 $2.5 \%$, CIP는 $1.3 \%$ 였다. 2007년 S. aureus 121 균주에 대한 내성률은 FUS는 $12.4 \%$, GEN $8.3 \%$, OXA 7.4\%, ERY 5.8\%, TET 1.7\%로 항 생제 내성을 보였다. 2008년 S. aureus 74균주에 대한 내성률은 FUS 13.5\%, GEN 8.1\%, CLI 6.8\%, ERY 5.4\%, TET 5.4\%, OXA $2.7 \%$ 를 나타냈다[21]. 본 연구에서도 FUS $14.7 \%$, TET $44.2 \%$, GEN 48.8\%, SXT 13.2\%, ERY 57.4\%, CLI 41.1\%, CIP 44.2\%였다. 2016년 내성률은 FUS 34.0\%, GEN 28.6\%, OXA 62.6\%, ERY $55.7 \%$, TET 34.7\%로 항생제 내성을 보였다. FUS는 2006년에 비 하여 2016년에 내성이 $19.3 \%$ 증가하였고, 감수성이 $12.4 \%$ 감소하 였으며, 통계적으로 유의하였다. 이러한 결과는 미국에서 진행한 FUS의 S. aureus 내성 관련 연구에서 2002년 99.8\% 억제하였으나 2014년에 내성이 증가된 보고와 일치한다[22]. 미국의 간호사 50 명을 대상으로 진행한 $\mathrm{MRSA}$ 의 항생제 내성평가와 이번 연구결과 와 비교하면 Tetracycline 50\%는 비슷한 비율을 나타내었으며, SXT 44\%로 이번 결과다 다소 낮은 경향을 나타내었고, CLI 33\% 는 비슷한 결과가 나타났으며, CIP와 ERY 22\%로 나타난 결과는 이번 연구와 다소 다른 결과를 나타냈다. 그리고 GEN $11 \%$ 의 내성을 나 타내었는데, 이번 연구결과에서는 $17.6 \%$ 정도 높은 결과를 나타내 었다. 2014년 1월 31일부터 12월 27일까지 호주에서 진행된 $\mathrm{MRSA}$ 항생제 내성연구에서는 $\mathrm{ERY}$ 과 $\mathrm{CIP}$ 에서 각각 $50 \%$ 의 내성을 나타내어 본 연구와 비슷한 결과를 나타내었고, tetracycline과 gentamicin에서 각각 $15 \%$ 의 내성을 나타내어 본 연구와 비슷한 결과를 나타내었다[24].

이번 연구에서는 2006년도와 2016년에서 대부분의 항생제들 은 차이가 없었는데, 이 부분은 지난 10년간 지속적인 항생제 내성 관리의 노력으로 생각된다. 실제로 질병관리본부는 2016년 7월 21일 세계보건기구(WHO)의 국제 항생제 내성 감시체계(Global Antimicrobial Resistance Surveillance System, GLASS)에 가입 하여 항생제 내성 현황을 모니터링하고 신속대응체계를 갖추고 있 다. 이번 연구결과에서 ERY, GEN, TET은 2016년 분리 균주가 2006년 분리 균주 보다 오리려 내성이 감소되었다. 이 부분은 2000년부터 시행된 의약분업과 2001년 항생제 사용 적정성 평가 시행 후 항생제 사용이 감소하였으며, 2010년 의약품에 관한 공정
거래 규약과 2012년부터 약제 급여 적정성 평가가 유 • 소아 급성 중이염까지 확대되고 예방적 항생제 사용 평가 결과를 등급화하는 요양급여 가감지급사업이 시행되어 항생제 사용에 대한 규제기관 의 평가와 감시는 더 세밀하고 광범위해진 결과로 생각된다[25]. 본 연구는 몇 가지 제한점이 있다. 첫째, 본 연구에서는 오염균의 가능 성이 높은 상처에서 분리하여 임상적인 의미의 해석 없이 분석하였 다. 둘째, 분리된 균들의 유전형을 평가를 하지 않았다. 셋째, 연구 기간 동안 항생제 사용량과 환자들의 인구학적 특성 및 중증도의 변화는 따로 고려하지 않았다. 결론적으로 일개 대학병원에서 10 년간의 항생제 감수성 검사의 결과의 차이는 결론적으로, 항생제의 감수성이 저하와 내성의 증가의 우려에도 불구하고 황색 포도상 구 균의 항균제 감수성에 큰 변화가 없었다. PEN은 여전히 높은 내성 을 나타내었고 OXA 또한 $60 \%$ 이상의 내성을 나타냈다. ERY, GEN, TET의 내성의 감소는 연구의 한계에서 제시하였듯이 복합 적인 연구가 필요할 것으로 생각한다. 그러나 이러한 결과는 의료 사회에서 항생제 오용과 남용에 관심의 높은 수준이 되었다는 것을 나타낼 수 있다. 그럼에도 불구하고 외래 환자에서 MRSA 분리 및 FUS 저항 비율의 증가 추세는 지역 사회를 포함하여 황색 포도상 구균 항생제 내성과 무분별한 처방의 원인이 될 수 있음을 시사한 다. 미생물 및 항균 감도의 변화의 주기적인 리뷰와 이해를 통해 적 절한 항생제 감수성을 지속적으로 연구해야 할 것으로 사료된다.

\section{요 약}

일반적으로 지역사회 관련 경로로 감염되기 쉬운 $S$. aureus는 대부분이 MSSA로 알려져 있었으나 최근 CA-MRSA가 증가하고 있 다. 항생제와 glycopeptides의 지속적인 남용은 VISA, VRSA가 더 욱 증가할 가능성이 있다. 본 연구는 최근 10 년간 일개 대학병원의 상처에서 분리한 황색 포도상 구균의 항생제 감수성 패턴과 항생제 내성의 유병률의 변화를 조사하기 위하여 실시 하였다. 본 연구에 서는 남성이 여성보다 항생제 내성이 높게 나타났다. 그리고 연령 에 따라 항생제 내성률이 증가하였다. 2006년 항생제 내성률은 penicillin, oxacillin, erythromycin, gentamicin, clindamycin, tetracycline, ciprofloxacin, fusidic acid, trimethoprim/sulfamethoxazole, clindamycin, rifampicin에서 각각 $97.7 \%, 60.5 \%$, $57.4 \%, 48.8 \%, 41.1 \%, 44.2 \%, 44.2 \%, 14.7 \%, 13.2 \%, 3.9 \%$ 나타났 으며, 2016년 항생제 내성률은 penicillin, oxacillin, erythromycin, gentamicin, clindamycin, tetracycline, ciprofloxacin, fusidic acid, trimethoprim/sulfamethoxazole, clindamycin, rifampicin 에서 각각 $95.9 \%, 62.6 \%, 55.7 \%, 28.6 \%, 50.3 \%, 34.7 \%, 38.8 \%$, $34.0 \%, 2.7 \%, 8.2 \%$ 로 나타났다. Vancomycin, linezolid, quinu- 
pristin/dalfopristin, teicoplanin 는 항생제 감수성에서 100\%를 나타내었다. 특히, fusidic acid는 2006년에 비하여 2016년에 내 성이 $19.3 \%$ 증가하였고, 감수성이 $12.4 \%$ 감소하였으며, 통계적으 로 유의하였다. 따라서, 미생물 및 항생제 변화의 주기적인 검토와 이해를 통해 적절한 항생제 감수성을 지속적으로 연구해야 할 것으 로 사료된다.

\section{Acknowledgements: None}

Funding: This study was financially supported by Dongnam Health University.

Conflict of interest: None

\section{References}

1. Ogston A. On abscesses. Rev Infect Dis, 1984;6(1):122-128.

2. Chambers HF, Deleo FR. Waves of resistance: Staphylococcus aureus in the antibiotic era. Nat Rev Microbiol. 2009;7(9):629641.

3. Jevons MP, Coe AW, Parker MT. Methicillin resistance in staphylococci. Lancet. 1963;1(7287):904-907.

4. Newsom SW. MRSA-past, present, future. J R Soc Med. 2004; 97(11):509-510.

5. Finberg RW, Moellering RC, Tally FP, Craig WA, Pankey GA, Dellinger EP, et al. The importance of bactericidal drugs: Future directions in infectious disease. Clin Infect Dis. 2004;39(9): 1314-20.

6. Wilkinson JD. Fusidic acid in dermatology. Br J Dermatol. 1998; 139(53):37-40.

7. Weisblum, B. Erythromycin resistance by ribosome modification. Antimicrob Agents Chemother. 1995;39(3): 577-585.

8. Wormser, GP, Keusch, GT, Heel RC. Co-trimoxazole (trimethoprim-sulfamethoxazole). Drugs. 1982;24(6):459-518.

9. Chambers HF, Deleo FR. Waves of resistance: Staphylococcus aureus in the antibiotic era. Nat Rev Microbiol. 2009;7(9):629641.

10. Miller LS, Cho JS. Immunity against Staphylococcus aureus cutaneous infections. Nat Rev Immunol. 2011;11(8):505-518.

11. Ruef C. Epidemiology and clinical impact of glycopeptide resistance in Staphylococcus aureus. Infection. 2004;32:315-327.

12. Fridkin SK, Hageman JC, Morrison M, Sanza LT, Como-Sabetti K, Jernigan JA, et al. Methicillin-resistant Staphylococcus aureus disease in three communities. N Engl J Med. 2005; 352(14):1436-1444.

13. Joo EJ, Chung DR, Ha YE, Park SY, Kang SJ, Kim SH, et al. Community-associated Panton-Valentine leukocidin-negative meticillin-resistant Staphylococcus aureus clone (ST72-MRSA-IV) causing healthcare-associated pneumonia and surgical site infection in Korea. J Hosp Infect. 2012;81(3):149-55.

14. Park SH, Park C, Yoo JH, Choi SM, Choi JH, Shin HH, et al. Emergence of community-associated methicillin-resistant Staphylococcus aureus strains as a cause of healthcare-associated bloodstream infections in Korea. Infect Control Hosp Epidemiol. 2009;30(2):146-155.

15. Clinical and Laboratory Standards Institute. Performance standards for antimicrobial susceptibility testing; 19th ed, CLSI document M100-S19. Wayne, PA: CLSI; 2009.

16. Wertheim HF, Melles DC, Vos MC, van Leeuwen W, van Belkum A, Verbrugh HA, et al. The role of nasal carriage in Staphylococcus aureus infections. Lancet Infect Dis. 2005;5:751-762.

17. Kitara L, Anywar A, Acullu D, Odongo-Aginya E, Aloyo J, Fendu M. Antibiotic susceptibility of Staphylococcus aureus in suppurative lesions in Lacor hospital, Uganda. African Health Sciences. 2011;11(3):34-39.

18. Lee K, Lee MA, Lee CH, Lee J, Roh KH, Kim S, et al. Increase of ceftazidime and fluoroquinolone-resistant Klebsiella pneumoniae and imipenem-resistant Acinetobacter spp. in Korea: Analysis of KONSAR study data from 2005 and 2007. Yonsei Med J. 2010;51:901-911.

19. Lee K, Lee MA, Lee CH, Lee J, Roh KH, Kim S, et al. Increase of ceftazidime and fluoroquinolone-resistant Klebsiella pneumoniae and imipenem-resistant Acinetobacter spp. in Korea: Analysis of KONSAR study data from 2005 and 2007. Yonsei Med J. 2010;51:901-911.

20. Kim HJ, Lee NY, Kim S, Shin JH, Kim MN, Kim EC, Koo SH, et al. Characteristics of microorganisms isolated from blood cultures at nine university hospitals in Korea during 2009. Korean J Clin Microbiol. 2011;14:48-54.

21. Lee JY, Wang HJ, Shin DB, Cho YS. Antibiotic resistance and bacterial biofilm formation by Staphylococcus aureus strains isolated from various foods. Korean J. Microbiol Biotechnol. 2013;41(1):96-104.

22. Farrell DJ, Mendes RE, Castanheira M, Jones RN. Activity of fusidic acid tested against Staphylococci isolated from patients in U.S. medical centers in 2014. Antimicrob Agents Chemother. 2016;60(6):3827-3831.

23. Shinde RV, Pawar SK, Mohite RV, Shinde AR, Duggu P. Study of nasal carriage of staphylococcus aureus with special reference to methicillin resistance among nursing staff. Arch Clin Microbiol. 2016;7:1-6.

24. Coombs GW, Daley DA, Thin Lee Y, Pearson JC, Robinson JO, Nimmo GR, et al. Australian group on antimicrobial resistance australian Staphylococcus aureus sepsis outcome programme annual report, 2014. Commun Dis Intell Q Rep. 2016;40(2): 244-254.

25. Kim BN. Overview of antibiotic use in Korea. Infection \& Chemotherapy. 2012;44(4):250-262. 